\title{
POTENTIAL TOXIC ELEMENTS (PTES) IN GROUND AND SPRING WATERS, SOILS AND SEDIMENTS: AN INTERDISCIPLINARY STUDY IN ANTHEMOUNTAS BASIN, N. GREECE
}

\author{
Kazakis N. ${ }^{1}$, Kantiranis N. ${ }^{1}$, Kaprara M. ${ }^{2}$, Mitrakas M. ${ }^{2}$, Vargemezis G.. \\ Voudouris K. ${ }^{1}$, Chatzipetros A. ${ }^{1}$, Kalaitzidou K. ${ }^{2}$ and Filippidis A. ${ }^{1}$ \\ ${ }^{1}$ Aristotle University of Thessaloniki, School of Geology, 54124, Thessaloniki, Greece, \\ kazakis@geo.auth.gr \\ ${ }^{2}$ Aristotle University of Thessaloniki, School of Chemical Engineering, Thessaloniki, Greece
}

\begin{abstract}
Ground and spring waters, soils and sediments of Anthemountas basin in Northern $G$ reece were analyzed for Potential Toxic Elements (PTEs). In total, twenty three soil and sediment samples, three groundwater (boreholes) and two spring water samples, were analyzed. Contents of Ni in soils and sediments can be as high as $2169 \mathrm{mg} / \mathrm{kg}$. The high correlation coefficient of $\mathrm{Ni}$ and $\mathrm{Cr}$, indicates the geogenic origin of $\mathrm{Ni}$, which originates from ophiolitic rocks. Arsenic concentration ranges from 3 to 110 $\mathrm{mg} / \mathrm{kg}$ in soils and sediments, with the highest contents observed in travertine. The spring waters are characterized by elevated concentrations of As (up to $235 \mu \mathrm{g} / \mathrm{L}$ ), $N$ $a, K, F e$ and $\mathrm{Zn}$, indicating that hydrothermal fluids are responsible for feldspar alte ration of the Monopigado granodiorite. On the contrary, in groundwaters, As conten ts are low (up to $18 \mu \mathrm{g} / \mathrm{L}$ ). Electrical resistivity tomographies performed around the groundwater boreholes, revealed the presence of normal faults, locally allowing the mixing of geothermal fluids with the shallow porous aquifer (SPA). The presence of As in the SPA is probably due to inputs from geothermal waters through normal faulting.
\end{abstract}

Keywords: Arsenic, Nickel, Travertine, Geothermal water, Faults, Ophiolites.

\section{Пєрí $\eta \psi \eta$}

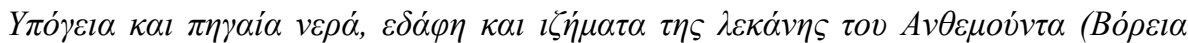

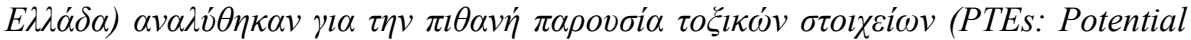

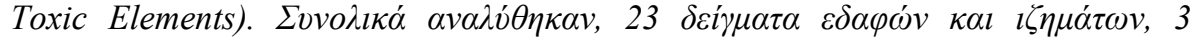

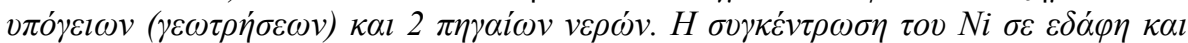

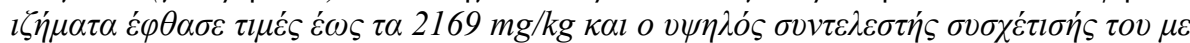

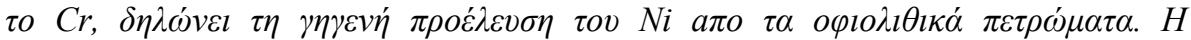

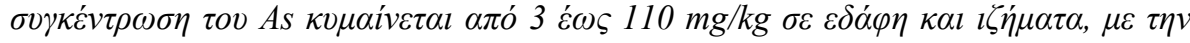

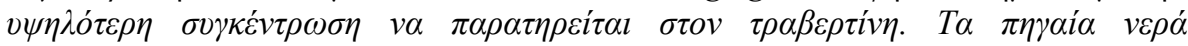

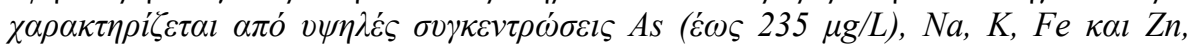

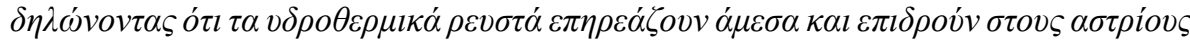

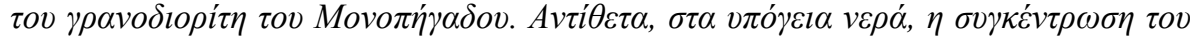

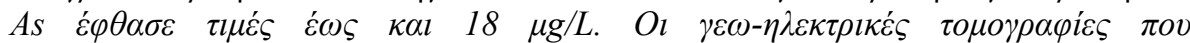

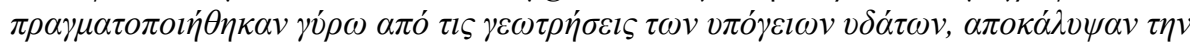

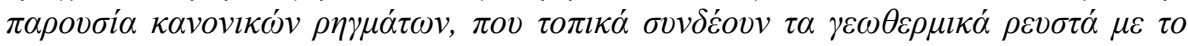




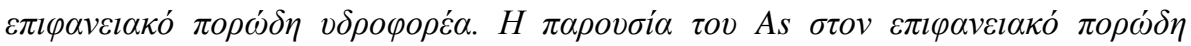

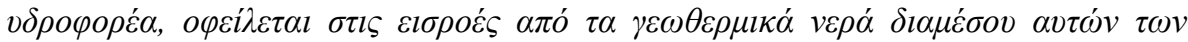

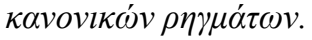

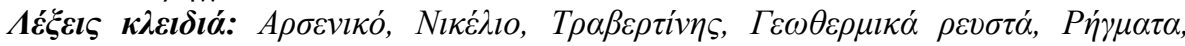

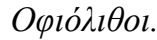

\section{Introduction}

Natural environments such as water, soil and air are under a constant risk of pollution due to population growth, agricultural activities and accelerated industrialization process (Morrison et al., 1990). Heavy metals are considered as one of the most serious environmental pollutants due to their persistence in the environment, bioaccumulation and high toxicity (Esmaeili et al., 2014; Assubaie, 2015). Heavy metals and Potential Toxic Elements (PTEs) can originate from two primary sources; anthropogenic such as agricultural practices, vehicle exhaust emissions, metalliferous mining and associated industries, whereas rock weathering and thermal springs constitute natural or geological inputs (Zhang et al., 1999; Gallego et al., 2002; Micó et al., 2006, Rodríguez Martín et al., 2007; Esmaeili et al., 2014). However, heavy metals and PTEs pollution in soils, sediments, plants, surface and groundwater is due to both natural processes and human activities and depends, among other things, on rock chemistry and mineral chemistry, the bioavailability of heavy metals and the different metallic and industrial mineral deposits that are exploited by humans (Papastergios et al., 2011; Petrotou et al., 2012; Skordas et al., 2013). Hexavalent chromium and arsenic are two of the most toxic elements in the environment and their consumption leads to carcinogenesis (Mandal and Suzuki, 2002; Linos et al., 2011). Weathering and erosion of ultramafic rocks has been recognized as a natural source of chromium in sediments and groundwater (Fantoni et al., 2002; Kaprara et al., 2015; Kazakis et al., 2015; Dermatas et al., 2015). The release of arsenic in groundwater can be due to the reductive dissolution of arsenic-bearing iron oxides (Harvey et al., 2002), the released As through sulfide oxidation reactions (Chowdhury et al., 1999) and the result of geothermal inputs (Nimik et al., 1998; Pique et al., 2010). Geothermal fluids circulating through faults can also be a source of As on groundwater and soils (Gamaletsos et al., 2013).

The Anthemountas river basin is characterized by a complex hydrogeological and hydrochemical regime with elevated concentrations of arsenic and chromium in groundwater (Kazakis, 2013). The geogenic origin of chromium and its distribution in aquifers has been clarified from previous studies (Kazakis et al., 2015). Nimfopoulos et al. (2002) reported elevated concentrations of heavy metals, PTEs and arsenic in the Geothermal springs water of the Anthemountas basin. Additionally, Tzamos et al. (2014) and Tziritis et al. (2015) reported low concentrations of heavy metals, PTEs and arsenic on tap water of Thermi Municipality.

This study aiming to explain the presence of the PTEs and heavy metal concentrations in soils, sediments, groundwater and geothermal springs' water in the Anthemountas basin. Therefore, previous studies (Kazakis, 2013; Kazakis et al., 2015) and new analytical data of soils, sediments a nd water were used to study the leaching mechanism of the most toxic elements $\mathrm{Cr}$ (VI) and As(III) (McCleskey et al., 2004). Additionally, this study focused in leaching from soils and sediments of the most toxic elements $\mathrm{Cr}(\mathrm{VI})$ and As. Moreover, electrical resistivity tomographies (ERT) were performed in selected sites in order to determine the hydrogeological conditions favoring elevated arsenic concentrations.

\section{Study site}

Anthemountas basin is placed in the eastern part of the Thermaikos Gulf in Northern Greece (Fig. 1). The site is characterized by a complex geological, hydrogeological and hydrochemical status due to the coexistence of various geological formations and aquifer types. Mesozoic igneous and metamorphic rocks, ultramafic rocks, together with granodiorite and recrystallized carbonates rocks are placed in the mountainous area surrounding the basin. The lowland comprises Quaternary and 
Neogene sediments of variable thickness. The Quaternary sediments consist of terrace systems (gravels, sands, pebbles and clays) and alluvial deposits (sands, gravels and sands with clay), whereas the Neogene sediments are composed of conglomerates, sandstones, marls and red-clay series. The sedimentary formations are the hosts of confined and unconfined porous aquifers with variable morphological characteristics. Fissured rock aquifers are developed in the crystalline and metamorphic rocks, whereas a karstic aquifer is located in the carbonate rocks. A detailed description of these aquifers' characteristics can be found in previous studies (Kazakis et al., 2015). In the study area, the water demands are met with groundwater resources and therefore aquifers' quality is of the utmost importance for the sustainability of the site. Consequently the origin and spatial distribution of pollutants are essential so as to prevent exposure of the population to toxic elements.

\section{Materials and Methods}

\subsection{Soil and sediment sampling, mineralogical and chemical characterization}

The soil and sediment sample sites were the same as those used in the study of Kazakis et al. (2015) in order to supplement the geochemical analysis of $\mathrm{Cr}$ and $\mathrm{Mn}$. Additionally, a sediment sample of travertine was collected from the Voskina spring. In total, 23 soil and sediment samples were collected at depths up $0.7 \mathrm{~m}$ by using a Dutch auger.

For the aluminosilicate mineral samples, a subsample of $0.2 \mathrm{~g}$ was placed in an open PTFE beaker where $1 \mathrm{~mL}$ of concentrated $\mathrm{HClO} 4$ and $20 \mathrm{~mL}$ of concentrated HF (Merck, pro-analysis) were added. The solution was then heated to fully evaporate $\mathrm{HF}$ and $\mathrm{HClO} 4$. Subsequently, $20 \mathrm{~mL}$ of $\mathrm{HCl}$ $6 \mathrm{~N}$ were added and the sample was heated for $30 \mathrm{~min}$. The solution was diluted to a final volume of $200 \mathrm{~mL}$ (Sparks et al., 1996). Metal concentrations were determined either by flame or graphite furnace atomic absorption spectrophotometry using a Perkin Elmer AAnalyst 800 instrument (GFAAS). For the determination of water-soluble fraction of As and $\mathrm{Cr}$ a $20 \mathrm{~g}$ sub-sample of soil was shaken with $60 \mathrm{~mL}$ deionized water for $15 \mathrm{~min}$ and then was filtered through a $0.45 \mu \mathrm{m}$ pore-size membrane filter. As and $\mathrm{Cr}$ concentrations in filtrate were determined by GF-AAS.

The morphological and mineralogical characteristics of the travertine sample were accurately deter mined by microprobe analysis of its minerals were determined by Scanning Electron Microscopy (SEM, JEOL JSM-840A) with associated Energy Dispersive Spectroscopy analysis (EDS, Link AN10000). To minimize volatilization of alkalis in the minerals framework, the electron beam spot size was enlarged and the counting time decreased. Different minerals (micas, carbonates, feldspars) and pure metals were used as probe standards.

\subsection{Water sampling and analysis}

Groundwater samples were collected from 2 springs (Voskina 1S and Agiasma 2S) and three boreholes from the shallow porous aquifer, following a two-hour (at least) pumping session for the boreholes (Fig. 1). All samples were collected in September 2015. The water samples were filtered through $0.45 \mu \mathrm{m}$ membrane filters. One part of each sample was acidified at $\mathrm{pH} 2$ using $\mathrm{HNO}_{3}$ and the other was analyzed immediately or refrigerated at $4{ }^{\circ} \mathrm{C}$ to be analyzed later. All analyses were conducted according to Clesceri et al. (1989). In particular, the parameters $\mathrm{pH}$ and electric conductivity (EC) were analyzed according to the methods APHA $4500-\mathrm{H}^{+}$and $2520 \mathrm{~B}$, respectively. The anions of bicarbonate $\left(\mathrm{HCO}_{3}^{-}\right)$, chloride $\left(\mathrm{Cl}^{-}\right)$, nitrate $\left(\mathrm{NO}_{3}^{-}\right)$, nitrite $\left(\mathrm{NO}_{2}{ }^{-}\right)$, phosphate $\left(\mathrm{PO}_{4}{ }^{3-}\right)$ and sulfate $\left(\mathrm{SO}_{4}{ }^{2-}\right)$ were determined according to the methods $2320 \mathrm{~B}, 4500 \mathrm{Cl}^{-}$ $\mathrm{F}, 4500 \mathrm{NO}_{3}{ }^{-} \mathrm{C}, 4500 \mathrm{NO}_{2}{ }^{-} \mathrm{B}, 4500 \mathrm{PC}$ and $4500 \mathrm{SO}_{4}{ }^{2-} \mathrm{B}$ respectively. The ammonium cation $\mathrm{NH}_{4}{ }^{+}$ was determined according to the $4500 \mathrm{NH}_{3} \mathrm{C}$ method. The concentration of water soluble metals was determined either by flame or GF-AAS. $\mathrm{Cr}(\mathrm{VI})$ concentrations were determined by the diphenylcarbazide method (3500-Cr D) using a Perkin Elmer Lambda 2 UV/VIS spectrophotometer version 3.7 equipped with $10 \mathrm{~cm}$ path-length measurement cells. Boron determination was 
performed by the azomethine $\mathrm{H}$ method and total organic carbon (TOC) content was measured to a Shimadzu TOC- $\mathrm{V}_{\mathrm{CSN}}$ Total Organic Carbon Analyzer.

\subsection{Electrical resistivity tomography (ERT)}

Three ERT lines were measured during the period of September 2011 near to the groundwater sample sites to detect structure which can facilitate the mixing between geothermal waters and fresh water of the upper aquifers system. Twenty-one stainless steel electrodes were used $50 \mathrm{~m}$ apart, forming a total length of $1000 \mathrm{~m}$ for each ERT line. Electrical resistivity measurements were performed using a SYSCAL Pro resistivity meter which was located in the center of the electrode array. Wenner array and configuration was used to accurately delineate the predicted horizontal structures and their interfaces (Loke, 2011), whereas dipole-dipole array configuration was also used to examine if lateral changes are significant. The reliability of the ERTs was tested with available lithological profiles and geological data and the best fitting array configuration was selected. The inversion of the mixed resistivity data set was performed using DC2DPRO software (Kim, 2009) and 2-D resistivity images were produced. Finally, the RMS error values of all ERTs ranged between 2 and $8 \%$ indicating the reliability of the measured data.

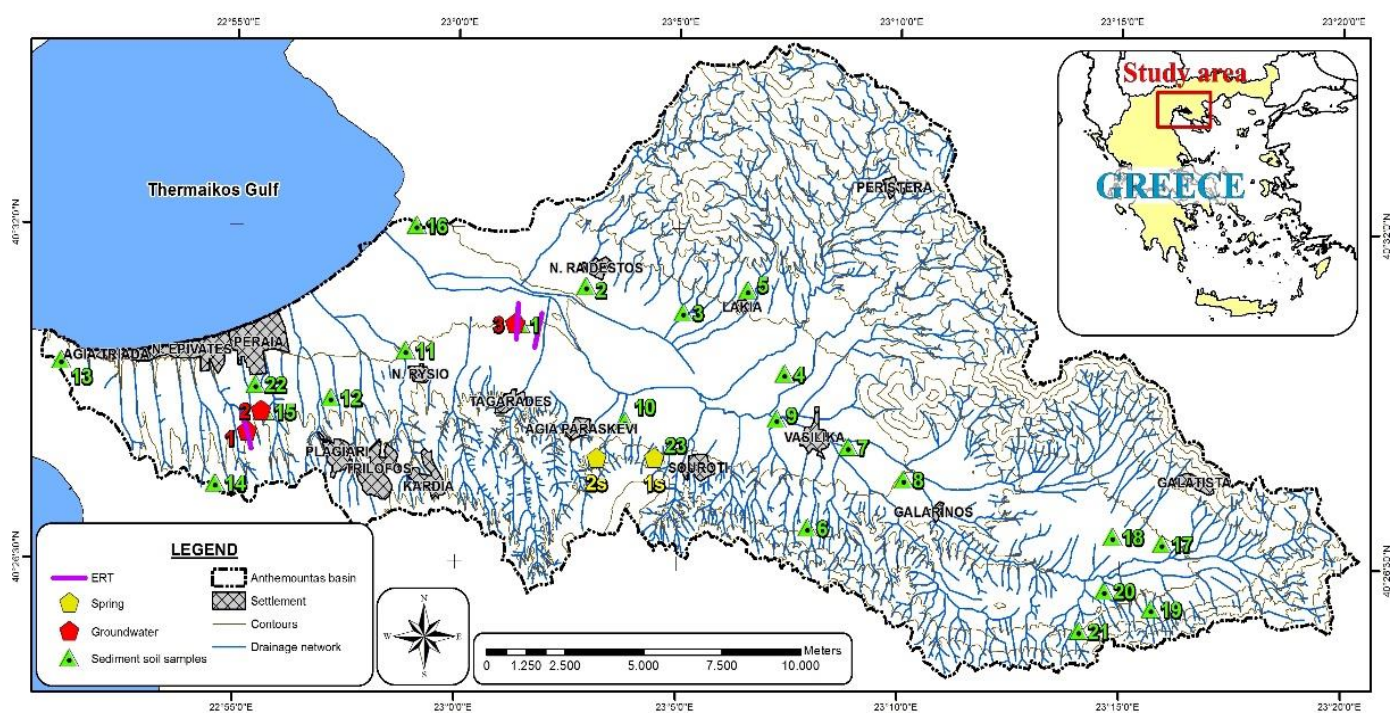

Figure 1 - Topographic map of Anthemountas river basin showing the sampling points.

\section{Results and discussion}

The minimum, maximum and mean values of the geochemical composition of soils and sediments are shown in Table 1. Total arsenic concentration in soils and sediments varies from 5 to $110 \mathrm{mg} / \mathrm{kg}$, whereas the highest concentration was recorded in the travertine sample, and leachable arsenic ranges between 3 and $58 \mathrm{mg} / \mathrm{kg}$. It is worth mentioning that leachable amounts of As from travertine were below the detection limit. Chromium and manganese content of travertine were 2 and 384 $\mathrm{mg} / \mathrm{kg}$ respectively which are low in comparison to the rest of samples from the study area. The leachable $\mathrm{Cr}(\mathrm{VI})$ concentration of soils and sediments range between 3 and $46 \mathrm{mg} / \mathrm{kg}$; the higher leachable amounts of $\mathrm{Cr}(\mathrm{VI})$ were observed in the samples with high serpentine content.

The concentrations of $\mathrm{Ni}, \mathrm{Pb}$ and $\mathrm{Zn}$ range between 7 and $2169 \mathrm{mg} / \mathrm{kg}, 1$ and 35 and 39 and 123 $\mathrm{mg} / \mathrm{kg}$, respectively. $\mathrm{Mg}$ contents range between 1.6 and $5.6 \mathrm{~g} / \mathrm{kg}$, while the higher values for $\mathrm{Mg}$ and $\mathrm{Ni}$ are located in the areas near the ophiolitic rocks. Sodium and potassium concentrations in soils and sediments range between 8.7 to 27.2 and 2.2 to $16.3 \mathrm{~g} / \mathrm{kg}$, respectively. Calcium varies from 13 to $375 \mathrm{~g} / \mathrm{kg}$ with an average concentration of $194 \mathrm{~g} / \mathrm{kg}$. The higher concentrations of calcium 
are found in soils and sediments nearby the carbonate rocks of the study area. Lead $(\mathrm{Pb})$ and zinc $(\mathrm{Zn})$ range between 1 to 35 and 39 to $123 \mathrm{mg} / \mathrm{kg}$, respectively.

Table 1 - Leachable As and $\mathrm{Cr}(\mathrm{VI})$ and geochemical composition of the studied soils and sedi ments.

\begin{tabular}{|c|c|c|c|c|c|c|c|c|c|c|c|c|c|c|}
\hline \multirow{2}{*}{ Values } & $\mathrm{Cr}^{1}$ & $\mathbf{M n}^{1}$ & $\mathbf{N i}$ & As & $\mathbf{P b}$ & $\mathbf{Z n}$ & Al & $\mathbf{C a}$ & $\mathrm{Fe}$ & $\mathbf{K}$ & Mg & $\mathrm{Na}$ & $\mathbf{A s} \mathbf{s}^{2}$ & $\mathrm{Cr}^{2}$ \\
\hline & \multicolumn{6}{|c|}{$\mathrm{mg} / \mathrm{kg}$} & \multicolumn{6}{|c|}{$\mathrm{g} / \mathrm{kg}$} & \multicolumn{2}{|c|}{$\mathrm{mg} / \mathrm{kg}$} \\
\hline Min & 2 & 384 & 7 & 5 & $\mathrm{ND}^{3}$ & 39 & 4.4 & 13 & 1.9 & 2.2 & 1.6 & 8.7 & ND & ND \\
\hline Max & 959 & 1630 & 2169 & 110 & 35 & 123 & 62.0 & 375 & 15.2 & 16.3 & 5.6 & 27.2 & 58 & 46 \\
\hline Mean & 303 & 964 & 350 & 22 & 20 & 74 & 33.2 & 194 & 8.6 & 9.3 & 3.6 & 18.0 & 15 & 8 \\
\hline $\mathrm{SD}^{4}$ & 245 & 314 & 524 & 28 & 9 & 17 & 13 & 78 & 3.2 & 3.4 & 1.2 & 5.9 & 11 & 9 \\
\hline $\mathrm{DL}^{3}$ & 50 & 50 & 1 & 1 & 1 & 1 & 1 & 0.1 & 0.05 & 0.05 & 0.1 & 0.05 & 1 & 1 \\
\hline
\end{tabular}

${ }^{1}$ Includes data from Kazakis et al., 2015; ${ }^{2}$ Leachable As and Cr $(\mathrm{VI}) ;{ }^{3}$ Not detected $;{ }^{4}$ Standard deviation; ${ }^{5}$ Detection limit.

A correlation analysis was performed between the elements and is shown in Table 2. The high correlation between $\mathrm{Cr}$ and $\mathrm{Mn}$ has been also referred in the study of Kazakis et al. (2015). Ni has high correlation with $\mathrm{Cr}, \mathrm{Mn}, \mathrm{Fe}$ and $\mathrm{Mg}$ and thus, it is concluded the geogenic origin of Ni from the weathering products of ophiolitic rocks. In contrast, the highest correlation of As was observed with $\mathrm{Na}$ and $\mathrm{K}$. This is probably an indication of the influence of hydrothermal fluids in feldsparrich clastic sediments and/or directly to the Monopigado granodiorite, causing the alteration of feldspars which enriches these fluids in $\mathrm{Na}$ and $\mathrm{K}$. The interaction between the geothermal field of Monopigado granodiorite field and the springs' hydrothermal fluid has been proposed by Nimfopoulos et al. (2002) based on Michard et al. (1998) study. Furthermore, the existence of a system of faults running through this igneous rock with ESE-NW direction favors the circulation of these fluids and the enrichment of groundwater in As and other heavy metals such as Fe, Mn and $\mathrm{Zn}$. Additionally, high correlation coefficient is observed between $\mathrm{Fe}$ and $\mathrm{Mn}$.

Table 2 - Correlation matrix of the elements from soils and sediments of the Anthemountas basin.

\begin{tabular}{|c|c|c|c|c|c|c|c|c|c|c|c|c|}
\hline & $\mathbf{C r}$ & $\mathbf{N i}$ & $\mathbf{M n}$ & $\mathbf{P b}$ & $\mathbf{Z n}$ & $\mathbf{A s}$ & $\mathbf{A l}$ & $\mathbf{C a}$ & $\mathbf{F e}$ & $\mathbf{M g}$ & $\mathbf{N a}$ & $\mathbf{K}$ \\
\hline $\mathbf{C r}$ & 1 & & & & & & & & & & & \\
\hline $\mathbf{N i}$ & $\mathbf{0 . 8 4 7}$ & 1 & & & & & & & & & & \\
\hline $\mathbf{M n}$ & $\mathbf{0 . 8 5 9}$ & $\mathbf{0 . 7 6 4}$ & 1 & & & & & & & & & \\
\hline $\mathbf{P b}$ & -0.244 & -0.172 & -0.122 & 1 & & & & & & & & \\
\hline $\mathbf{Z n}$ & -0.145 & 0.034 & 0.044 & 0.224 & 1 & & & & & & & \\
\hline $\mathbf{A s}$ & 0.072 & -0.006 & 0.070 & -0.635 & 0.192 & 1 & & & & & & \\
\hline $\mathbf{A l}$ & -0.577 & -0.713 & -0.311 & -0.086 & 0.187 & 0.370 & 1 & & & & & \\
\hline $\mathbf{C a}$ & -0.388 & -0.313 & -0.502 & 0.095 & -0.198 & -0.177 & -0.265 & 1 & & & & \\
\hline $\mathbf{F e}$ & $\mathbf{0 . 7 9 8}$ & $\mathbf{0 . 7 3 7}$ & $\mathbf{0 . 8 3 7}$ & -0.470 & 0.177 & 0.539 & -0.201 & -0.450 & 1 & & & \\
\hline $\mathbf{M g}$ & $\mathbf{0 . 8 4 2}$ & $\mathbf{0 . 8 8 6}$ & 0.698 & -0.203 & -0.068 & 0.039 & -0.772 & -0.053 & 0.700 & 1 & & \\
\hline $\mathbf{N a}$ & -0.094 & -0.161 & -0.040 & -0.555 & 0.219 & $\mathbf{0 . 9 6 8}$ & 0.531 & -0.180 & 0.414 & -0.146 & 1 & \\
\hline $\mathbf{K}$ & -0.277 & -0.302 & -0.226 & -0.422 & 0.351 & $\mathbf{0 . 9 0 1}$ & 0.570 & -0.108 & 0.222 & -0.306 & $\mathbf{0 . 9 4 3}$ & 1 \\
\hline
\end{tabular}

Scanning electron microscopy (Fig. 2) of the travertine sample revealed the presence of an amorph ous $\mathrm{Fe}$-As rich phase deposited as irregular masses scattered throughout the surface of travertine. $\mathrm{T}$ his denotes the arsenic deposition together with iron oxides-hydroxides (oxidized forms of iron) on 
the carbonate phases of travertine (Nimfopoulos et al., 2002). The latter is rich in $\mathrm{CaCO}_{3}$ phases, e specially calcite, as revealed from the X-ray diffraction analysis.

Groundwater samples were collected from two springs and three boreholes. Their statistical values ar e presented in Table 3 . The electrical conductivity varies from 1127 to $6334 \mu \mathrm{S} / \mathrm{cm}$, the higher values being observed in spring waters. In the spring waters and borehole 3, the $\mathrm{pH}$ is slightly acidic (6.2-6. 5), while in boreholes 1 and 2 is neutral to slightly alkaline (7.8). Nitrate concentrations are mainly lo $\mathrm{w}(<22 \mathrm{mg} / \mathrm{L})$, while the highest concentration was observed in borehole 3 . Sodium and potassium co ncentrations range from 105 to 950 and 2.6 to $70.9 \mathrm{mg} / \mathrm{L}$, respectively, while the highest concentratio ns were observed in the spring waters. These confirm our opinion that the hydrothermal fluids directl $\mathrm{y}$ affect and alter the feldspars of the Monopigado granodiorite. Also, the highest concentrations of $\mathrm{Cl}$ (up to $132512 \mathrm{mg} / \mathrm{L}$ ) were observed in spring waters.
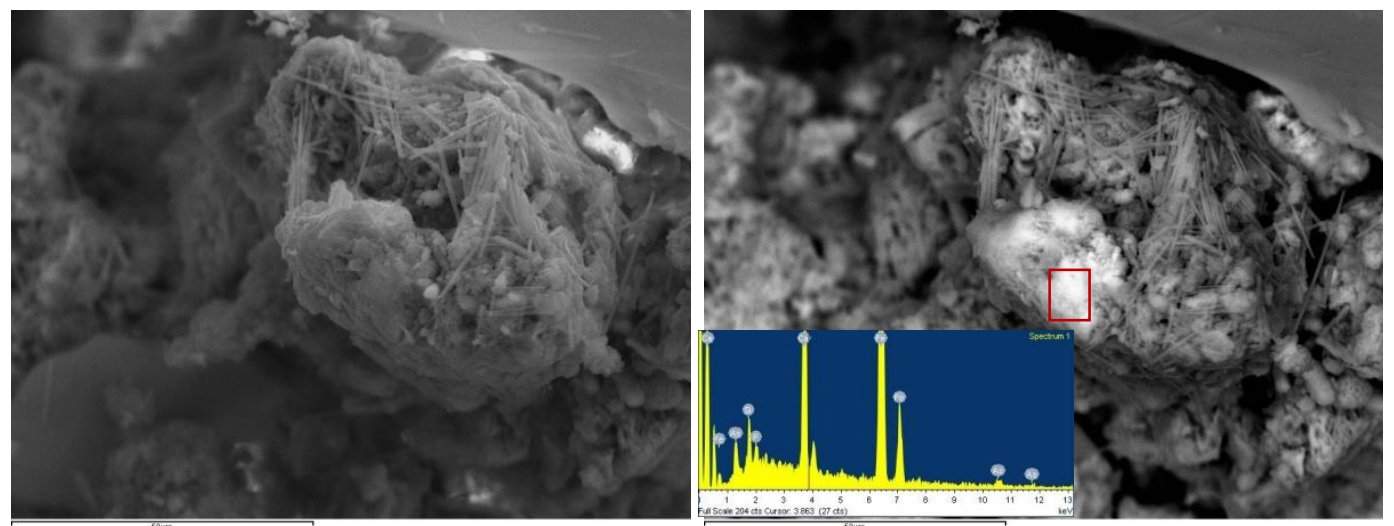

Figure 2 - Microphotograph (normal-left, backscattered-right) of travertine sample and micr oprobe analysis of Fe-As rich phase deposit on the Ca-rich travertine surface.

The concentrations of $\mathrm{Hg}, \mathrm{Pb}, \mathrm{Cu}, \mathrm{Cr}, \mathrm{Cr}(\mathrm{VI})$ and $\mathrm{Sb}$ were below the corresponding detection limit. Cobalt was detected only in the spring water of Agiasma $(6 \mu \mathrm{g} / \mathrm{L})$. Iron and manganese vary from 204 to 6667 and 96 to $1264 \mathrm{mg} / \mathrm{L}$, respectively. The highest concentration of boron was observed in the borehole $3(9.5 \mathrm{mg} / \mathrm{L})$, whereas in the Voskina and Agiasma springs the concentrations were 8.3 and $7.8 \mathrm{mg} / \mathrm{L}$, respectively. In borehole 2 the concentration of B was below detection limit, while in borehole 1 the concentration was $2.4 \mathrm{mg} / \mathrm{L}$. Arsenic concentrations in the studied samples range from 3 to $235 \mu \mathrm{g} / \mathrm{L}$. The highest concentration was observed in Agiasma spring and the lowest in the borehole 3 . Concentration in the Voskina spring was $30 \mu \mathrm{g} / \mathrm{L}, 18 \mu \mathrm{g} / \mathrm{L}$ in borehole 1 and $7 \mu \mathrm{g} / \mathrm{L}$ in borehole 2 .

Electrical resistivity tomographies were performed near the boreholes 1 and 3 in order to detect faults which can serve as paths for geothermal waters in the course of being mixed with the fresh waters of the shallow porous aquifers. Figure 3 depicts the electrical conductivity (Kazakis, 2013) of the boreholes around the ERT lines and the ERT. ERTs confirm the existence of faults with resistivity values up to $10 \mathrm{Ohm}-\mathrm{m}$. The low resistivity value in the fault bodies is due to the circulation of geothermal fluids.

The fault orientation in the site of borehole 3 is ENE-WSW, whereas the faults are normal and parallel to the Anthemountas fault. It is located in the boundary between the alluvial deposits and the terrace system. In the site of borehole 1, the orientation of the fault wasn't determined due to the absence of a second ERT. The fault is located in the sandstone-marl series two kilometres south of the Peraia town.

Summarizing the results of this study, the groundwater quality of the shallow porous aquifer is locally affected by geothermal fluids. The geothermal water connected through the faults with the upper aquifer and mixed with fresh groundwater. The elevated concentrations of As and the related trace elements in groundwater of the study area are probably associated with the geothermal waters. 
Table 3 - Statistical characteristics of groundwater and spring water samples.

\begin{tabular}{|c|c|c|c|c|c|c|}
\hline Parameter & Units & Detection Limit & Mean & Max & Min & St. Dev \\
\hline $\mathrm{pH}$ & & & 6.9 & 7.8 & 6.2 & 0.83 \\
\hline E.C. & $\mu \mathrm{S} / \mathrm{cm}$ & & 3326 & 6334 & 1127 & 2209 \\
\hline Total Hardness & ${ }^{\circ} \mathrm{F}$ & & 69.5 & 106.7 & 27.3 & 34.6 \\
\hline Carbonate Hardness & ${ }^{\circ} \mathrm{F}$ & & 62.4 & 106.7 & 27.3 & 38.4 \\
\hline Non-Carbonate Hardness & ${ }^{\circ} \mathrm{F}$ & & 17.7 & 24.7 & 10.7 & 10.88 \\
\hline Alkalinity (M) & & & 12.3 & 25.2 & 6.9 & 7.81 \\
\hline Alkalinity (P) & & & ND & ND & ND & ND \\
\hline$\left(\mathrm{HCO}_{3}^{-}\right)$ & $\mathrm{mg} / \mathrm{L}$ & 5 & 847 & 1537 & 418 & 547 \\
\hline$\left(\mathrm{CO}_{3-}^{2-}\right)$ & $\mathrm{mg} / \mathrm{L}$ & 5 & ND & ND & ND & ND \\
\hline$\left(\mathrm{Cl}^{-}\right)$ & $\mathrm{mg} / \mathrm{L}$ & 2 & 629.2 & 1325.0 & 110.0 & 518.14 \\
\hline$\left(\mathrm{SO}_{4}^{2-}\right)$ & $\mathrm{mg} / \mathrm{L}$ & 2 & 66.8 & 144.0 & 35.0 & 45.21 \\
\hline$\left(\mathrm{NO}_{2}^{-}\right)$ & $\mathrm{mg} / \mathrm{L}$ & 0.01 & 0.1 & 0.2 & 0.01 & 0.08 \\
\hline$\left(\mathrm{NO}_{3}^{-}\right)$ & $\mathrm{mg} / \mathrm{L}$ & 2 & 8.8 & 22.0 & 2.0 & 8.89 \\
\hline$\left(\mathrm{PO}_{4}{ }^{3-}\right)$ & $\mathrm{mg} / \mathrm{L}$ & 0.01 & 0.1 & 0.2 & 0.0 & 0.07 \\
\hline$\left(\mathrm{Na}^{+}\right)$ & $\mathrm{mg} / \mathrm{L}$ & & 434 & 950 & 105 & 351 \\
\hline$\left(\mathrm{K}^{+}\right)$ & $\mathrm{mg} / \mathrm{L}$ & & 22.9 & 70.9 & 2.6 & 28.96 \\
\hline$\left(\mathrm{Ca}^{2+}\right)$ & $\mathrm{mg} / \mathrm{L}$ & & 190 & 375 & 35 & 160 \\
\hline$\left(\mathrm{Mg}^{2+}\right)$ & $\mathrm{mg} / \mathrm{L}$ & & 53.5 & 97.0 & 31.4 & 26.77 \\
\hline$\left(\mathrm{Li}^{+}\right)$ & $\mathrm{mg} / \mathrm{L}$ & 0.01 & 1.0 & 2.6 & 0.04 & 1.11 \\
\hline$\left(\mathrm{Sr}^{2+}\right)$ & $\mathrm{mg} / \mathrm{L}$ & 0.05 & 1.5 & 2.0 & 1.2 & 0.35 \\
\hline$\left(\mathrm{NH}_{4}{ }^{+}\right)$ & $\mathrm{mg} / \mathrm{L}$ & 0.05 & 3.1 & 5.0 & 1.2 & 2.17 \\
\hline (Sb) & $\mu \mathrm{g} / \mathrm{L}$ & 2 & ND & ND & ND & ND \\
\hline (As) & $\mu \mathrm{g} / \mathrm{L}$ & 1 & 58.6 & 235.0 & 3.0 & 99.2 \\
\hline$(\mathrm{Cd})$ & $\mu \mathrm{g} / \mathrm{L}$ & 0.1 & 0.2 & 0.2 & 0.2 & 0.09 \\
\hline $\mathrm{Cr}(\mathrm{VI})$ & $\mu \mathrm{g} / \mathrm{L}$ & 1 & $\mathrm{ND}$ & ND & ND & ND \\
\hline$(\mathrm{Cr})$ & $\mu \mathrm{g} / \mathrm{L}$ & 1 & $\mathrm{ND}$ & ND & ND & ND \\
\hline$(\mathrm{Cu})$ & $\mu \mathrm{g} / \mathrm{L}$ & 50 & ND & ND & ND & ND \\
\hline$(\mathrm{Fe})$ & $\mu \mathrm{g} / \mathrm{L}$ & 50 & 1594 & 6667 & 204 & 2840 \\
\hline$(\mathrm{Pb})$ & $\mu \mathrm{g} / \mathrm{L}$ & 1 & ND & ND & ND & ND \\
\hline (Mn) & $\mu \mathrm{g} / \mathrm{L}$ & 20 & 427 & 1264 & 96 & 481 \\
\hline (Ni) & $\mu \mathrm{g} / \mathrm{L}$ & 1 & 11.0 & 21.0 & 1.8 & 9.56 \\
\hline (Co) & $\mu \mathrm{g} / \mathrm{L}$ & 1 & 6.0 & 6.0 & 6.0 & - \\
\hline (Mo) & $\mu \mathrm{g} / \mathrm{L}$ & 2 & 4.1 & 6.3 & 2.0 & 2.48 \\
\hline$(\mathrm{Zn})$ & $\mu \mathrm{g} / \mathrm{L}$ & 10 & 70.8 & 194.0 & 22.0 & 72.03 \\
\hline$(\mathrm{Hg})$ & $\mu \mathrm{g} / \mathrm{L}$ & 0.2 & ND & ND & ND & ND \\
\hline (B) & $\mathrm{mg} / \mathrm{L}$ & 0.05 & 7.0 & 9.5 & 2.4 & 4.15 \\
\hline $\mathrm{SiO}_{2}$ & $\mathrm{mg} / \mathrm{L}$ & 2 & 23.8 & 27.0 & 20.0 & 2.77 \\
\hline T.O.C. & $\mathrm{mg} / \mathrm{L}$ & 0.5 & 3.5 & 7.4 & 0.7 & 3.12 \\
\hline
\end{tabular}

The geothermal origin of As is also supported by the elevated concentrations of $\mathrm{As}, \mathrm{Na}, \mathrm{K}, \mathrm{Fe}$ and $\mathrm{Zn}$ in the travertine sample. The Ni in soils and sediments of the study area has a geogenic origin from the weathering products of the ophiolitic rocks.

The small number of the groundwater samples is the main limitation of this study in order to make a representative map of As concentration in the aquifers of the Anthemountas basin. However, it is important to the origin of As in porous aquifers from geothermal waters. The geological sources of As in Greece are reported by Gamaletsos et al. (2013). Geothermal inputs of As in groundwater have been also reported from Mitrakas (2001) and Pique et al. (2010) in the Caldes de Malavella geothermal area in Spain. A future study, with a higher number of groundwater samples would be 
beneficial for the determination of As distribution in porous aquifers of the study area. In Greece, elevated concentration of arsenic in groundwater have been reported in many regions (Katsoyiannis et al., 2007; Voudouris et al., 2014) indicating the need for a consistent and detailed monitoring of As in groundwater. Additionally, speciation of As should be performed in future studies in order to determine the form of arsenic (As(III) or As(V)) on groundwater considering that the toxicity of $\mathrm{As}(\mathrm{V})$ is significantly lower from As(III).

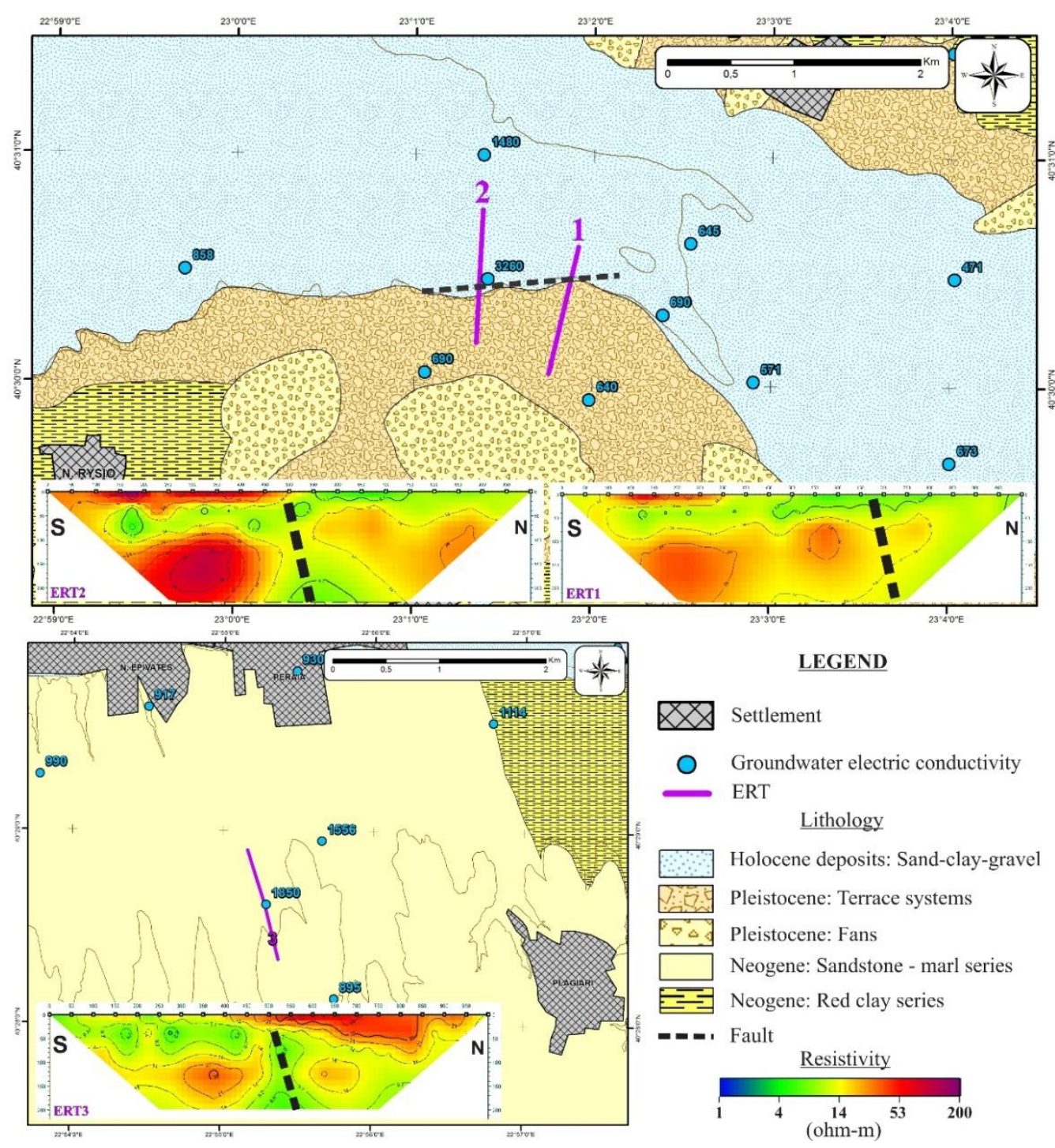

Figure 3 - Geological maps with ERTs and groundwater electrical conductivity.

\section{Conclusions}

In the Anthemountas river basin, a variable geochemical composition was occurred in soils and sediment samples. Nickel concentrations were up to $2169 \mathrm{mg} / \mathrm{kg}$ and the highest values located near to the ophiolitic rocks. The high correlation coefficient between $\mathrm{Cr}$ and $\mathrm{Ni}$ indicates the geogenic origin of $\mathrm{Ni}$ in the Anthemountas basin. Arsenic concentrations range from 3 to $110 \mathrm{mg} / \mathrm{kg}$ in soils and sediments, while the highest concentration observed in travertine. Spring waters are characterized by elevated concentrations of As (up to $235 \mu \mathrm{g} / \mathrm{L}$ ), $\mathrm{Na}, \mathrm{K}, \mathrm{Fe}$ and $\mathrm{Zn}$, and can be 
assumed, particularly by the presence of $\mathrm{Na}$ and $\mathrm{K}$, that hydrothermal fluids directly affect and alter the feldspars of the Monopigado granodiorite. In groundwater samples from the studied boreholes As concentrations are equal or below $18 \mu \mathrm{g} / \mathrm{L}$. Electrical resistivity tomographies have revealed the existence of normal faults which facilitate the mixing between geothermal waters and fresh water of the upper porous aquifers.

The interdisciplinary approach and results of this study can be used as a tool to identify aquifers prone to high As concentrations originating from geothermal waters. However, a more detailed mapping of As distribution in the aquifers of Anthemountas basin is necessary in order to prevent exposure of the population to As.

\section{Acknowledgements}

This research was carried out within the framework of the Post Doc of Nerantzis Kazakis and was funded by the State Scholarships Foundation of Greece (I.K.Y.) through the Program "IKY FELLOWSHIPS OF EXCELLENCE FOR POSTGRADUATE STUDIES IN GREECE SIEMENS PROGRAM".

\section{References}

Assubaie, F.N., 2015. Assessment of the levels of some heavy metals in water in Alahsa Oasis farms, Saudi Arabia, with analysis by atomic absorption spectrophotometry, Arabian Journal of Chemistry, 8, 240-245.

Chowdhury, T.R., Basu, G.K., Mandal, B.K., Biswas, B.K., Samanta, G., Chowdhury, U.K., Chanda, C.R., Lodh, D., Roy, S.L., Saha, K.C., Roy, S., Kabir, S., Quamruzzaman, Q. and Chakraborti, D., 1999. Arsenic poisoning in the Ganges Delta, Nature, 401, 545-546.

Clesceri, L., Greenberg, A. and Trussell, R., 1989. Standard Methods for the Examination of Water and Wastewater, 17th edition. APHA-AWWA-WEF, Washington DC.

Dermatas, D., Mpouras, T., Chrysochoou, M., Panagiotakis, I., Vatseris C., Linardos, N., Theologou, E., Boboti, N., Xenidis, A., Papassiopi, N. and Sakellariou, L., 2015. Origin and concentration profile of chromium in a Greek aquifer, Journal of Hazardous Materials, 281, $35-46$.

Esmaeili, A., Moore, F., Keshavarzi, B., Jaafarzadeh, N. and Kermani, M., 2014. A geochemical survey of heavy metals in agricultural and background soils of the Isfahan industrial zone, Iran, Catena, 121, 88-98.

Fantoni, D., Brozzo, G., Canepa, M., Cipolli, F., Marini, L., Ottonelo, G., Vetuschi and Zuccolini, M., 2002. Natural hexavalent chromium in groundwaters interacting with ophiolitic rocks, Environmental Geology, 42(8), 871-882.

Gallego, J.L.R., Ordonez, A. and Loredo, J., 2002. Investigation of trace element sources from an industrialized area (Aviles, northern Spain) using multivariate statistical methods, Environ. Int., 27, 589-596.

Gamaletsos, P., Godelitsas, A., Dotsika, E., Tzamos, E., Gotthlicher, J. and Filippidis, A., 2013. Geological sources of As in the Environment of Greece: A review. In: The Handbook of Environmental Chemistry, vol. 40. Threats to the Quality of Groundwater Resources: Prevention and Control, Scozzari, A. and Dotsika, E., eds., Springer-Verlag, Berlin Heidelberg, 77-113.

Harvey, C.F., Swartz, C.H., Badruzzaman, A.B.M., Keon-Blute, N., Yu, W., Ali, M.A., Jay, J., Beckie, R., Niedan, V., Brabander, D., Oates, P.M., Ashfaque, K.N., Islam, S., Hemond, H.F. and Ahmed, M.F., 2002. Arsenic mobility and groundwater extraction in Bangladesh, Science, 298, 1602-1606.

Kazakis, N., 2013. Groundwater Pollution Risk Assessment in Anthemountas Basin, PhD thesis, Department of Geology, Aristotle University of Thessaloniki (in Greek). 
Kazakis, N., Kantiranis, N., Voudouris, K.S., Mitrakas, M., Kaprara, E. and Pavlou, A., 2015. Geogenic $\mathrm{Cr}$ oxidation on the surface of mafic minerals and the hydrogeological conditions influencing hexavalent chromium concentrations in groundwater, Science of the Total Environment, 514, 224-238.

Kaprara, E., Kazakis, N., Simeonidis, K., Coles, S., Zoumboulis, A.I., Samaras, P. and Mitrakas, M., 2015. Occurrence of $\mathrm{Cr}$ (VI) in drinking water of Greece and relation to the geological background, J. Hazard. Materials, 281, 2-11.

Katsoyiannis, I., Hug, S., Ammann, A., Zikoudi, A. and Hatziliontos, C., 2007. Arsenic speciation and uranium concentrations in drinking water supply wells in Northern Greece: Correlation $\mathrm{s}$ with redox indicative parameters and implications for groundwater treatment, Science of the Total Environment, 383, 128-140.

Kim, J.H., 2009. DC2DPro-2D Interpretation System of DC Resistivity Tomography, User's Manual and Theory, KIGAM, S. Korea.

Linos, A., Petralias, A., Christophi, C.A., Christoforidou, E., Kouroutou, P., Stoltidis, M., Veloudaki, A., Tzala, E., Makris, K.C. and Karagas. M.R., 2011. Oral ingestion of hexavalent chromium through drinking water and cancer mortality in an industrial area of Greece - an ecological study, Environ., Health 10(50), 1-8.

Loke, M.H., 2011. Electrical resistivity surveys and data interpretation. In: Gupta, H.K., ed., Encyclopedia of Solid Earth Geophysics. $2^{\text {nd }}$ edition, Springer, 276-283.

Mandal, B.K. and Suzuki, K.T., 2002. Arsenic round the world: a review, Talanta, 58, 201-235.

McCleskey, R.B., Nordstrom, D.K. and Maest, A.S., 2004. Preservation of water samples for arsenic(III), Applied Geochemistry, 19, 995-1009.

Methods of Soil Analysis, 1996. Part 3 - Chemical Methods. In: Sparks, D.L., ed., Soil Science Society of America, Madison, WI, USA.

Michard, A., Feinberg, H. and Montigny, R., 1998. The Chalkidiki supra-ophiolitic formations, and their bearing on the Vardarian obduction process, Bull. Geol. Soc. of Greece, 32(1), 59-64.

Micó, C., Recatalá, L., Peris, M. and Sánchez, J., 2006. Assessing heavy metal sources in agricultural soils of an European Mediterranean area by multivariate analysis, Chemosphere, $65,863-872$.

Mitrakas, M., 2001. A survey of arsenic levels in tap, underground, and thermal mineral waters of Greece, Fresenius Environmental Bulletin, 10(6), 717-721.

Morrison, G.M.P., Revitt, D.M. and Ellis, J.B., 1990. Metal Speciation in Separate Stormwater Systems, Water Science Technology, 22, 53.

Nimik, D.A., Moore, J.N., Dalby, C.E. and Savka, M.W., 1998. The fate of geothermal arsenic in the Madison and Missouri Rivers, Montana and Wyoming, Water Resources Research, 34(11), 3051-3067.

Nimfopoulos, M.K., Hadjispyrou, S.A., Polya, D.A., Michailidis, K.M. and Trontsios, G., 2002. Geochemical conditions and environmental pollution from hydrothermal waters of the Anthemous basin, Thessaloniki district, N. Greece, 6th Pan-Hellenic Geographical Conference (Volume II), Thessaloniki 2002, 428-435.

Papastergios, G., Filippidis, A., Fernandez-Turiel, J.L., Gimeno, D. and Sikalidis, C., 2011. Surface soil geochemistry for environmental assessment in Kavala Area, northern Greece, Water, Air, \& Soil Pollution, 216, 141-152.

Petrotou, A., Skordas, K., Papastergios, G. and Filippidis, A., 2012. Factors affecting the distribution of potentially toxic elements in surface soils around an industrialized area of northwestern Greece, Environmental Earth Sciences, 65, 823-833.

Pique, A., Grandia, F. and Canals, A., 2010. Processes releasing arsenic to groundwater in the Caldes de Malavella geothermal area, NE Spain, Water Research, 44, 5618-5630.

Rodríguez Martín, J.A., Vázquez de la Cueva, A., Grau Corbí, J.M. and López Arias, M., 2007. Factors controlling the spatial variability of copper in topsoils of the Northeastern Region of the Iberian Peninsula, Spain, Water, Air, \& Soil Pollution, 186, 311-321. 
Voudouris, K., Melfos, V., Aidona, E., Kazakis, N., Giouri, K. and Stratis, J., 2014. Arsenic concentration in groundwater and sediments of Velestino area, Thessaly, Central Greece. Proc. of 10th International Hydrogeological Conference, 8-10 October 2014, Thessaloniki, 1, 759-770.

Skordas, K., Papastergios, G. and Filippidis, A., 2013. Major and trace element contents in apples from a cultivated area of central Greece, Environ. Monitoring \& Assessment, 185, 8465-8471.

Tzamos, E., Tziritis, E., Vogiatzis, P., Matzari, C., Kantiranis, N., Filippidis, A., Theodosiou, N. and Fytianos, K., 2014. Suitability of potable groundwater reserves of Thermi Municipality (Macedonia, Northern Greece) and definition of main hydrogeochemical signatures, Proc. of $12^{\text {th }}$ Intern. Conf. "Protection \& Restoration of the Environment", Skiathos, 6-3 July, 272-276.

Tziritis, E., Tzamos, E., Vogiatzis, P., Matzari, C., Kantiranis, N., Filippidis, A., Theodosiou, N. and Fytianos, K., 2015. Quality assessment and hydrogeochemical status of potable water resources in a suburban area of northern Greece (Thermi Municipality, central Macedonia), Desalination and Water Treatment, doi: 10.1080/19443994.2015.1052993.

Zhang, C., Selinus, O. and Kjellstrom, G., 1999. Discrimination between natural background and anthropogenic pollution in environmental geochemistry - exemplified in an area of southeastern Sweden, Science of the Total Environment, 243-244, 129-140. 